\title{
First evidence of crayfish plague agent in populations of the marbled crayfish (Procambarus fallax forma virginalis)
}

\author{
N.S. Keller ${ }^{(1)}$, M. Pfeiffer ${ }^{(2)}$, I. Roessink ${ }^{(3)}$, R. Schulz ${ }^{(1)}$, A. Schrimpf ${ }^{(1), \star}$
}

Received August 15, 2014

Revised October 14, 2014

Accepted October 15, 2014

Key-words:

Marbled

crayfish, crayfish plague agent, exotic pathogen, invasive species, real-time $P C R$

\section{ABSTRACT}

The introduction of non-indigenous species and associated diseases can cause declines in indigenous flora and fauna and threaten local biodiversity. The crayfish plague pathogen (Aphanomyces astaci), carried and transmitted by latent infected North American crayfish, can lead to high mortalities in indigenous European crayfish populations. Although the parthenogenetic marbled crayfish (Procambarus fallax (Hagen, 1870) forma virginalis) is common in the aquarium trade and has established wild populations in Europe, its carrier status is still unknown. This study investigated one captive and three established wild-living marbled crayfish populations for an infection with the crayfish plague pathogen applying real-time PCR. We demonstrate that captive, as well as two wild marbled crayfish populations were infected by $A$. astaci. Although infection status in laboratory kept specimens reached high levels, marbled crayfish showed no obviously plague-related mortality. Furthermore, sequence analysis revealed that captive crayfish carried the $A$. astaci genotype Pc, which has earlier been isolated from the North American red swamp crayfish (Procambarus clarkii). The results indicate that due to its positive carrier status marbled crayfish poses a greater threat to local biodiversity in Europe than considered until now.

\section{RÉSUMÉ}

Première mise en évidence de l'agent de la peste de l'écrevisse dans des populations de l'écrevisse marbrée (Procambarus fallax f. virginalis)

\begin{abstract}
Mots-clés : écrevisse marbrée, agent de la peste de l'écrevisse, agent pathogène exotique, espèce envahissante,
\end{abstract}


PCR en temps réel de la peste des écrevisses en appliquant la PCR en temps réel. Nous démontrons que deux populations d'écrevisses marbrées sauvages ainsi que celle en captivité étaient infectées par $A$. astaci. Bien que l'infection en laboratoire présente des spécimens atteints à des niveaux élevés, les écrevisses marbrées ne présentent pas de mortalité évidente liée à la peste. En outre, l'analyse des séquences a révélé que les écrevisses captives portent le génotype $\mathrm{Pc}_{\mathrm{c}} \mathrm{d}$ 'A. astaci, qui a été précédemment isolé de l'écrevisse rouge des marais nord-américaine (Procambarus clarkii). Les résultats indiquent qu'en raison de son statut de porteur l'écrevisse marbrée constitue une plus grande menace pour la biodiversité locale en Europe que considéré jusqu'à présent.

\section{INTRODUCTION}

From the end of the 19th century and onwards non-indigenous crayfish species (NICS) from North America, like spiny-cheek crayfish (Orconectes limosus), signal crayfish (Pacifastacus leniusculus) and red swamp crayfish (Procambarus clarkii), were introduced in Europe (Alderman, 1996; Holdich et al., 2009). Besides unintended introductions, e.g. by escaping pet specimen, the main reason for their importations was intentional stockings (Lilley et al., 1997). For example, the signal crayfish was stocked into natural waters to replace indigenous noble crayfish (Astacus astacus) populations, which have been lost because of crayfish plague outbreaks (Vennerström et al., 1998). Although the intentional release of NICS today is restricted in most European countries, the three above mentioned "Old NICS" (i.e. NICS introduced before 1975) have already established numerous populations throughout Europe (Holdich et al., 2009; Kouba et al., 2014). Presently, a wide variety of different North American crayfish are popular as pets in the aquarium trade, especially in Germany and the Netherlands, and the extensive trade of crayfish species as pets leads to further releases of these animals into nature from aquaria (Chucholl, 2013) and garden ponds (Patoka et al., 2014). Despite that scientist promote a ban on the supply and keeping of NICS in aquaria as pets, crayfish availability via aquarium trade, fairs, and internet sales is still increasing in many European countries (Chucholl, 2013).

One of the common crayfish species found in the North American and European pet trade is the marbled crayfish (Procambarus fallax (Hagen, 1870) forma virginalis) (Faulkes, 2010). It was introduced into Germany via pet trade in the mid 1990s (Chucholl and Pfeiffer, 2010) and became popular due to its extraordinary reproduction strategy, the apomictic parthenogenesis (Scholtz et al., 2003; Martin et al., 2007, 2010). The first wild-living marbled crayfish were found in 2003 in a dredging pool near Eggenstein-Leopoldshafen (near Karlsruhe, Germany) only one km away from the River Rhine, but without any surface water connection to the river (Marten et al., 2004). Today at least six wild established populations are known, most of them from Germany (Chucholl et al., 2012). In Europe, the species has also been reported in the wild occurring in Sweden (Bohman et al., 2013), the Netherlands, Italy and Slovakia (Kouba et al., 2014). Once established, NICS are often more competitive than indigenous crayfsh species (Schulz et al., 2006) but they also displace indigenous crayfish species due to associated diseases carried by them (Holdich et al., 2009).

North American crayfish are natural hosts and carriers of the crayfish plague pathogen, the oomycete Aphanomyces astaci (Unestam and Weiss, 1970; Alderman, 1996). A. astaci is a crayfish parasite (Unestam, 1969) but can also infect two crab species (Eriocheir sinensis and Potamon potamios) (Svoboda et al., 2014; Schrimpf et al., 2014). The cysts of the pathogen can survive in freshwater for a few days or in mud for a couple of weeks and give rise to new zoospores which infect the animals (Cerenius and Söderhäll, 1985; Longshaw, 2011). Although North American crayfish are usually resistant to this pathogen and only act as carriers, they can succumb and die from the infection under stressful conditions (Söderhäll and Cerenius, 1992). In contrast, indigenous European crayfish are highly vulnerable and an infection usually leads to high mortality rates (Longshaw, 2011). Today five genotypes of $A$. astaci, 
which can be assigned to different host species, are known and they seem to vary in their virulence (Makkonen et al., 2012b; Viljamaa-Dirks et al., 2013). Genotypes Ps1 and Ps2 have been assigned to signal crayfish (Huang et al., 1994), Pc to red swamp crayfish (DiéguezUribeondo et al., 1995) and Or has been identified on spiny-cheek crayfish (Kozubíková et al., 2011). Genotype As has only been identified on native European crayfish species, but until now the original host species in Europe is unknown (Makkonen et al., 2012a; Viljamaa-Dirks et al., 2013). The genotypes of infected calico crayfish (Orconectes immunis) as well as virile crayfish (Orconectes virilis), that have been found to be carrier of $A$. astaci (Schrimpf et al., 2013a; Tilmans et al., 2014), are not yet identified.

Although Culas (2003) had claimed to have detected $A$. astaci DNA in two marbled crayfish specimen (Culas, 2003), her results cannot be regarded as reliable because a later work has shown that the applied PCR method is not specific for $A$. astaci, instead also related Aphanomyces-species show a positive signal (Oidtmann et al., 2006). Hence, the carrier status of the parthenogenetic marbled crayfish is still unknown. Therefore, the intention of this study was to investigate captive and wild-living marbled crayfish populations for an infection with the crayfish plague pathogen applying species-specific and quantitative real-time PCR (qPCR). Furthermore, we aimed to determine the $A$. astaci genotype of infected marbled crayfish using sequence analysis. The species could either carry a yet unknown genotype or be carrier of a known genotype due to overlapping habitats, species contact, as well as impurities and exchange through aquarium trade.

\section{MATERIAL AND METHODS}

We captured eleven wild-living marbled crayfish with traps and by hand from the Pond in Klepzig (0.025 ha, Sachsen-Anhalt, Germany), and 28 from the Lake Singliser near Borken (74 ha, Hessen, Germany). From the Lake Moosweiher located near Freiburg in the Upper River Rhine catchment (7.6 ha, Baden-Wuerttemberg, Germany), where marbled crayfish is coexisting with spiny-cheek crayfish, we collected 23 marbled crayfish and 28 spiny-cheek crayfish. In Lake Singliser, the marbled crayfish presence was first suspected in October 2010 and one year later, in October 2011, actual proof of its occurrence had been delivered. Being of unknown origin, it was presumed that the animals were released from an aquarium (Dümpelmann and Bonacker, 2012). The first confirmation of a marbled crayfish presence in Lake Moosweiher was provided in July 2009 (Pfeiffer, 2010). Although the lake already contained an established population of spiny-cheek crayfish, marbled crayfish also established a population in Lake Moosweiher. Also here the origin of the population is unknown. Furthermore, 33 marbled crayfish were obtained from a lab culture at Alterra, Wageningen (The Netherlands). The culture was already in-house for approximately six years after founding individuals were purchased from a hobby breeder.

DNA was extracted from the soft abdominal cuticle, the inner joint of two walking legs and parts of the uropods using a CTAB-method as described in Vrålstad et al. (2009). To assess the infection status of marbled crayfish, we conducted a TaqMan ${ }^{\circledR}$ minor groove binder (MGB) qPCR, targeting the ITS region according to Vrålstad et al. (2009) with some modifications (Schrimpf et al., 2013a). Infection status and agent level from the A. astaci-specific qPCR are based on the numbers of observed PCR forming units (PFU) and were defined according to Vrålstad et al. (2009). DNA samples with an agent levels of $A 2$ (5 PFU $\left.\leqslant \mathrm{PFU}_{\text {obs }}<50 \mathrm{PFU}\right)$ and higher (A3: 50 PFU $\leqslant$ PFU $_{\text {obs }}<10^{3}$ PFU; A4: $10^{3}$ PFU $\leqslant$ PFU $_{\text {obs }}<10^{4}$ PFU; A5: $10^{4}$ PFU $\leqslant \mathrm{PFU}_{\text {obs }}<10^{5} \mathrm{PFU}$ ) are considered infected with $A$. astaci and samples with A0 (0 PFU) and $\mathrm{A} 1$ ( $\mathrm{PFU}_{\mathrm{obs}}<5 \mathrm{PFU}$ ) are considered uninfected. $A$. astaci prevalence in marbled crayfish populations as well as $95 \%$ confidence intervals were estimated according to Filipová et al. (2013) using the function "epi.conf" (included in package epiR) with RStudio version 0.98.501. The genotype of $A$. astaci was identified using sequence analysis of a 370 base pair fragment of the chitinase gene according to Makkonen et al. (2010) with some modifications. We have used $5 \times$ PCR buffer, $2 \mu \mathrm{M} \mathrm{MgCl}_{2}, 0.025$ u TaqMan ${ }^{\circledR}$ Taq (all Promega, Mannheim, Germany), $0.2 \mu \mathrm{M}$ dNTP (Fermentas, St. Leon-Rot, Germany), $0.2 \mu \mathrm{M}$ primers AAChiF and 


\section{Table I}

qPCR results for one laboratory cultured marbled crayfish population, two wild-living marbled crayfish population and one coexisting population of marbled crayfish (MC) and spiny-cheek crayfish (SC) from sampling sites in Germany. Shown is the number $(N)$ of tested individuals, their detected agent level ( $A O$ to A5, considering A0 (O PFU) and A1 (PFU obs $<5$ PFU) uninfected and A2 (5 PFU $\leqslant P F U_{\text {obs }}<50 P F U$ ), A3 (50 PFU $\leqslant$ PFU obs $<10^{3}$ PFU), A4 (10 $\left.\mathrm{PFU} \leqslant \mathrm{PFU}_{\mathrm{obs}}<10^{4} \mathrm{PFU}\right)$ and $\mathrm{A5}\left(10^{4} \mathrm{PFU} \leqslant P F U_{\mathrm{obs}}<\right.$ $10^{5} \mathrm{PFU}$ ) infected), the absolute number of infected individuals, $A$. astaci prevalence in different marbled crayfish populations as well as $95 \%$ confidence intervals.

\begin{tabular}{|c|c|c|c|c|c|c|c|c|c|c|c|}
\hline \multirow{2}{*}{ Origin } & \multirow{2}{*}{ Species } & \multirow{2}{*}{$N$} & \multicolumn{6}{|c|}{ Agent level } & \multicolumn{2}{|c|}{ Infected } & \multirow{2}{*}{$95 \% \mathrm{Cl}$} \\
\hline & & & $A 0$ & $\overline{A 1}$ & A2 & $A B$ & $\overline{A 4}$ & $A 5$ & $N$ & $\%$ & \\
\hline Laboratory cultured & $\mathrm{MC}$ & 33 & 9 & 1 & 16 & 5 & $1^{*}$ & $1^{*}$ & 23 & 70 & (53-83\%) \\
\hline Klepzig & $\mathrm{MC}$ & 11 & 8 & 2 & 1 & & & & 1 & 9 & $(2-38 \%)$ \\
\hline Lake Moosweiher & $\mathrm{MC}$ & 23 & 16 & 5 & 2 & & & & 2 & 9 & $(2-27 \%)$ \\
\hline Lake Moosweiher & SC & 28 & 20 & 7 & 1 & & & & 1 & 4 & $(1-18 \%)$ \\
\hline Lake Singliser & $\mathrm{MC}$ & 28 & 28 & & & & & & 0 & 0 & $(0-12 \%)$ \\
\hline
\end{tabular}

*Samples used for the sequence analysis.

AAChiR and added 1.5 $\mu \mathrm{L}$ template DNA for a final volume of $12.5 \mu \mathrm{L}$. PCR products were sequenced on a 3730 DNA Analyzer eight capillary sequencer (Applied Biosystems, MA, USA). The sequences were edited with the program Geneious R7 (Drummond et al., 2011) and submitted to GenBank (accession number: KP100541). Reference sequences of genotypes As, Ps1, Ps2, Pc were received from J. Makkonen (University of Eastern Finland) and a reference sequence of the genotype group Or was generated from a pure culture sample (strain Li05, isolated from O. limosus from the stream Litavka, see Kozubíková-Balcarová et al. (2013)) received from A. Petrusek (Charles University in Prague), respectively. Multiple alignments with our sequences were created and the genotype was determined by comparison of our sequences to the reference sequences. Based on the matching mutations the genotypes could be assigned.

\section{RESULTS}

The results from the qPCR revealed that 23 out of $33(70 \%)$ marbled crayfish individuals from the lab culture were infected with $A$. astaci (Table I). Agent levels ranged from $\mathrm{A} 2$ to A5. In the marbled crayfish population from Lake Singliser, however, no traces of $A$. astaci DNA could be detected, while in the population from Klepzig one of eleven marbled crayfish (9\%) was infected with $A$. astaci. In the population from Lake Moosweiher two of 23 marbled crayfish (9\%) were $A$. astaci positive as well as one of $28(4 \%)$ of the coexisting spiny-cheek crayfish. All positive crayfish individuals collected from the wild yielded only agent level $A 2$, corresponding to very low agent levels. Since the detection of the $A$. astaci genotype is rarely possible for agent levels lower or equal to A3 (Makkonen et al., 2012a) only for two of the samples from the lab culture with agent level A4 and A5 the genotype of $A$. astaci could be determined. This revealed that the laboratory cultured individuals were carrying the $\mathrm{PC}_{\mathrm{C}}$ genotype.

\section{DISCUSSION}

This study revealed that marbled crayfish in captivity as well as in nature were infected with the crayfish plague agent. While wild-living individuals showed a low agent level (A2), caged marbled crayfish were more heavily infected, up to agent level A5 (Table I). The high agent levels of the marbled crayfish from the lab culture might be explained by the additional stress caused by the indoor situation and the captivity (dense population, restricted space) which weakens their immune system (Söderhäll and Cerenius, 1992) and facilitates the spread of A. astaci in the crayfish body. Moreover, the successful spread of $A$. astaci zoospores rises 
with increasing density of crayfish (Kozubíková et al., 2009) and the capability of the crayfish to cope with the infection decreases with increasing spore density (Oidtmann, 2012). Strand et al. (2011) have detected higher density of spores in indoor tanks, compared to outdoor ponds where spores are heterogeneous distributed due to higher spore dynamics, patchy distributed crayfish and more water per crayfish and $A$. astaci spores. Although no obvious signs of a crayfish plague infection (e.g. high mortality, lack of coordination, loss of escape reflex (Alderman et al., 1987; Oidtmann, 2012)) were observed, the zoospore density in the aquarium might be higher than in nature and could lead to higher agent levels of marbled crayfish.

In two out of three wild-living marbled crayfish populations a low $A$. astaci infection could be verified. However, the number of samples was relatively small $(N=11$ to 28$)$ and due to environmental stochasticity (Dwyer et al., 2004) or recent molting events (Oidtmann, 2012), the infection status with $A$. astaci may have been underestimated. The analysis of 28 individuals seems to indicate that the population from Lake Singliser is A. astaci free (Schrimpf et al., 2013b). However, a more intensive sampling could possibly still increase detection probability ( $95 \%$ confidence interval ranged from 0 to $12 \%$ ) of $A$. astaci.

The OIE (2012) recommends either a conventional PCR analysis followed by the sequence analysis of the ITS-region or the QPCR by Vrålstad et al. (2009) to confirm the crayfish plague agent in tissue material. We have applied the more sensitive qPCR. As an additional confirmation we have sequenced a fragment of the chitinase gene according to Makkonen et al. (2010) and compared it to reference sequences of $A$. astaci from pure culture. The comparision served as species identification as well as genotype assignment.

Interestingly the captive marbled crayfish from the aquarium carried the known genotype Pc, which has earlier been isolated from the warm-water favouring North American red swamp crayfish. In addition, the assigned genotype Pc is physiologically adapted to warm temperatures (Diéguez-Uribeondo et al., 1995) and the spores, compared to other strains $\left(4-20^{\circ} \mathrm{C}\right)$, grow better at higher temperatures up to $27^{\circ} \mathrm{C}$ (Oidtmann, 2012). Altough marbled crayfish also prefer warm habitats with water temperatures $>15^{\circ} \mathrm{C}$ (Chucholl and Pfeiffer, 2010), we cannot differentiate if marbled crayfish originally carried genotype Pc or if the population became infected with this genotype due to contaminations in the aquarium trade or the laboratory. The latter is a possibility, since other crayfish species were maintained in the same laboratory room as well. Although there was no water flow from one tank to another, crosscontaminations while feeding or handling the animals cannot be excluded. Unfortunately, the detection of the $A$. astaci genotype was not possible in samples with lower agent levels from the wild populations. The failure to determine the genotype of low infected crayfish by chitinase sequencing analysis has been frequently observed (Makkonen, person. comm.) and could be explained by the lower sensibility of the traditional PCR compared to qPCR (Tuffs and Oidtmann, 2011) and the lower copy number of the chitinase gene compared to the multycopy-gene ITS targeted in the qPCR. In Lake Moosweiher marbled crayfish coexist with spiny-cheek crayfish for at least five years (Chucholl and Pfeiffer, 2010) and on spiny-cheek crayfish from the Czech Republic the genotype Or has been identified in the past (Kozubíková et al., 2011). Thus, if the source of the $A$. astaci infection in marbled crayfish was spiny-cheek crayfish, we would expect both species to carry genotype Or. But it is also possible that the spiny-cheek crayfish population was uninfected and got infected from marbled crayfish. Further investigations might clarify the situation.

Infected non-indigenous crayfish usually act as permanent reservoirs of $A$. astaci and once such a reservoir is present in nature, the pathogen can infect other indigenous and nonindigenous populations through contaminated water, fishing gear or animals (Oidtmann, 2012). Besides transmitting crayfish plague, marbled crayfish can also threat indigenous European species by competition for resources and high reproduction rates due to high growth rate and early fertility (Marten et al., 2004). Marbled crayfish favor summer-warm lentic habitats with water temperatures $>15{ }^{\circ} \mathrm{C}$. Hence, it is expected that marbled crayfish can reproduce and establish stable populations, in addition to recent distribution areas (Germany, Sweden, the Netherlands, Italy and Slovakia), in France, parts of England, Eastern Europe, 
as well as the Iberian and the Balkan Peninsula, including the potential to coexist with other North American species (Chucholl and Pfeiffer, 2010). Although marbled crayfish could establish viable populations in these areas, environmental factors (e.g. food sources) often limit the population growth and spread in nature (Marten et al., 2004).

According to Holdich et al. (2009) "New NICS" can be more easily controlled, managed or eliminated than the more common "Old NICS" because the chance to control a species is higher when the species is not yet widespread. Altough the eradication of a restricted, isolated signal crayfish population in a small pond using chemical treatment, pharmaceutical BETAMAX VET ${ }^{\circledR}$, and draining appeared to be successful, the application to larger water systems will probaly not have the same success (Sandodden and Johnsen, 2010). Furthermore, with a chemical treatment it cannot be assured that only the target species will be eliminated. Therefore, we cannot consider the chemical treatment as a save way to completely control invasive crayfish species. Especially the control and eradication of parthenogenetic species that only need one female to establish viable populations (Marten et al., 2004) might be a challenge in future.

Since their introductions "Old NICS" from North America, e.g. signal crayfish, spiny-cheek crayfish and red swamp crayfish, became the greatest threat to indigenous crayfish species due to transmission of crayfish plague and habitat loss as a result of direct competition (Holdich et al., 2009). Hence, the marbled crayfish is a much greater menace than previously known, because our results confirm that this highly reproductive species is infected with the crayfish plague agent. Therefore, there is an urgent need to minimize the risk of further introductions of marbled crayfish into nature. Conservation measures including the education of pet traders, local stakeholders and fisher man is one important measure in halting the further spread of NICS.

\section{ACKNOWLEDGEMENTS}

We would like to thank Christoph Dümpelmann, Rainer Hennings and Wolfgang Wendt for providing samples. We thank Adam Petrusek (Charles University in Prague) for providing A. astaci DNA from pure culture for genotype comparison and Jenny Makkonen (University of Eastern Finland) for providing sequence alignments of $A$. astaci genotypes.

\section{REFERENCES}

Alderman D.J., Polglase J.L. and Frayling M., 1987. Aphanomyces astaci pathogenicity under laboratory and field conditions. J. Fish Dis., 10, 385-393.

Alderman D.J., 1996. Geographical spread of bacterial and fungal diseases of crustaceans. Rev. sci. tech. Off. int. Epiz., 15, 603-632.

Bohman P., Edsman L., Martin P. and Scholtz G., 2013. The first Marmorkrebs (Decapoda: Astacida: Cambaridae) in Scandinavia. Biolnvasions Records, 2, 227-232.

Cerenius L. and Söderhäll K., 1985. Repeated zoospore emergence as a possible adaptation to parasitism in Aphanomyces. Experimental Mycology, 9, 259-263.

Chucholl C. and Pfeiffer M., 2010. First evidence for an established Marmorkrebs (Decapoda, Astacida, Cambaridae) population in Southwestern Germany, in syntopic occurrence with Orconectes limosus (Rafinesque, 1817). Aquat. Invas., 5, 405-412.

Chucholl C., Morawetz K. and Groß H., 2012. The clones are coming - strong increase in Marmorkrebs (Procambarus fallax (Hagen, 1870)). Aquat. Invas., 7, 511-519.

Chucholl C., 2013. Invaders for sale: trade and determinants of introduction of ornamental freshwater crayfish. Biol. Invasions, 15, 125-141.

Culas A., 2003. Entwicklung einer molekularbiologischen Methode zum Nachweis des Krebspesterregers Aphanomyces astaci SCHIKORA in nordamerikanischen Flusskrebsen (Pacifastacus leniusculus; Orconectes limosus; Procambarus clarkii). Dissertation, LudwigMaximilians-Universität München. 
Diéguez-Uribeondo J., Huang T., Cerenius L. and Söderhäll K., 1995. Physiological adaption of an Aphanomyces astaci strain isolated from the freshwater crayfish Procambarus clarkii. Mycol. Res., 99, 574-578.

Dümpelmann C. and Bonacker F., 2012. Erstnachweis des Marmorkrebses Procambarus fallax $f$. virginalis (Decapoda: Cambaridae) in Hessen. Forum Flusskrebse, 18, 3-14.

Drummond A., Ashton B., Buxton S., Cheung M., Cooper A., Duran C., Field M., Heled J., Kearse M., Markowitz S., Moir R., Stones-Havas S., Sturrock S., Thierer T and Wilson A., 2011. GENEIOUS Pro v 7 (computer program). Retrieved from http://www.geneious.com.

Dwyer G., Dushoff J. and Yee S.H., 2004. The combined effects of pathogens and predators on insect outbreaks. Nature, 430, 341-345.

Faulkes Z., 2010. The spread of the parthenogenetic marbled crayfish, Marmorkrebs (Procambarus sp.), in the North American pet trade. Aquat. Invas., 5, 447-450.

Filipová L., Petrusek A., Matasová K., Delaunay C. and Grandjean F., 2013. Prevalence of the crayfish plague pathogen Aphanomyces astaci in populations of the signal crayfish Pacifastacus leniusculus in France: evaluating the threat of native crayfish. PLOS ONE, 8, 1-10.

Holdich D.M., Reynolds J.D., Souty-Grosset C. and Sibley P.J., 2009. A review of the ever increasing threat to European crayfish from non-indigenous crayfish species. Knowl. Manage. Aquat. Ecosyst., 394-395, 11.

Huang T.S., Cerenius L. and Söderhäll K., 1994. Analysis of genetic diversity in the crayfish plague fungus, Aphanomyces astaci, by random amplification of polymorphic DNA. Aquaculture, 126, 1-10.

Kouba A., Petrusek A. and Kozák P., 2014. Continental-wide distribution of crayfish species in Europe: update and maps. Knowl. Manage. Aquat. Ecosyst., 413, 05.

Kozubíková E., Filipová L., Kozák P., Ïuriš Z., Martín M.P., Diéguez-Uribeondo J., Oidtmann B. and Petrusek A., 2009. Prevalence of the Crayfish Plague Pathogen Aphanomyces astaci in Invasive American Crayfish in the Czech Republic. Conserv. Biol., 23, 1204-1213.

Kozubíková E., Viljamaa-Dirks S., Heinikainen S. and Petrusek A., 2011. Spiny-cheek crayfish Orconectes limosus carry a novel genotype of the crayfish plague pathogen Aphanomyces astaci. J. Invertebr. Pathol., 108, 214-216.

Kozubíková-Balcarová E., Koukol O., Martín M.P., Svoboda J., Petrusek A. and Diéguez-Uribeondo J., 2013. The diversity of oomycetes on crayfish: Morphological vs. molecular identification of cultures obtained while isolating the crayfish plague pathogen. Fungal Biol., 117, 682-691.

Lilley J.H., Cerenius L. and Söderhäll K., 1997. RAPD evidence for the origin of crayfish plague outbreaks in Britain. Aquaculture, 157, 181-185.

Longshaw M., 2011. Diseases of crayfish: A review. J. Invertebr. Pathol., 106, 54-70.

Makkonen J., Jussila J., Henttonen P. and Kokko H., 2010. Crayfish plague (Aphanomyces astaci) can be vertically transferred during artificial incubation of crayfish eggs: preliminary results. Freshw. Crayfish, 17, 151-153.

Makkonen J., Jussila J. and Kokko H., 2012a. The diversity of the pathogenic oomycete (Aphanomyces astaci) chitinase genes within the genotypes indicate adaptation to its hosts. Fungal Genetics and Biology, 49, 635-642.

Makkonen J., Jussila J., Kortet R., Vainikka A. and Kokko H., 2012b. Differing virulence of Aphanomyces astaci isolates and elevated resistance of noble crayfish Astacus astacus against crayfish plague. Dis. Aquatic Organ., 102, 129-136.

Marten M., Werth C. and Marten D., 2004. Der Marmorkrebs (Cambaridae, Decapoda) in Deutschland ein weiteres Neozoon im Einzugsgebiet des Rheins. Lauterbornia, 50, 17-23.

Martin P., Kohlmann K. and Scholtz G., 2007. The parthenogenetic Marmorkrebs (marbled crayfish) produces genetically uniform offspring. Naturwissenschaften, 94, 843-846.

Martin P., Dorn N.J., Kawai T., von der Heiden C. and Scholtz G., 2010. The enigmatic Marmorkrebs (marbled crayfish) is the parthenogenetic form of Procambarus fallax (Hagen, 1870). Contributions to Zoology, 79, 107-118.

Oidtmann B., 2012. Crayfish plague (Aphanomyces astaci). Chapter 2.2.1. In: Manual of Diagnostic Tests for Aquatic Animals 2012. Office international des épizooties, Paris, pp 101-118, http://www.oie. int/international-standard-setting/aquaticmanual/access-online, accessed 2 June 2014. 
Oidtmann B., Geiger S., Steinbauer P., Culas A. and Hoffmann R.W., 2006. Detection of Aphanomyces astaci in North American crayfish by polymerase chain reaction. Dis. Aquatic Organ., 72, 53-64.

Patoka J., Petrtýl M. and Kalous L., 2014. Garden ponds as potential introduction pathway of ornamental crayfish. Knowl. Manage. Aquat. Ecosyst., 13, 414.

Pfeiffer M., 2010. Mitteilung: Marmorkrebs Procambarus spec. (Cambaridae, Decapoda) im Moosweiher bei Freiburg im Breisgau. Forum Flusskrebse, 13, 29-32.

Sandodden R. and Johnsen S.I., 2010. Eradication of introduced signal crayfish Pasifastacus leniusculus using the pharmaceutical BETAMAX VET ${ }^{\circledR}$. Aquat. Invas., 5, 75-81.

Schrimpf A., Chucholl C., Schmidt T and Schulz R., 2013a. Crayfish plague agent detected in populations of the invasive North American crayfish Orconectes immunis (Hagen, 1870) in the Rhine River, Germany. Aquat. Invas., 8, 103-109.

Schrimpf A., Maiwald T., Vrålstad T., Schulz H.K., Smietána P. and Schulz R., 2013b. Absence of the crayfish plague pathogen (Aphanomyces astaci) facilitates coexistence of European and American crayfish in central Europe. Freshw. Biol., 58, 1116-1125.

Schrimpf A., Schmidt T. and Schulz R., 2014. Invasive Chinese mitten crab (Eriocheir sinensis) transmits crayfish plague pathogen (Aphanomyces astaci). Aquat. Invas., 9, 203-209.

Scholtz G., Braband A., Tolley L., Reimann A., Mittmann B., Lukhaup C., Steuerwald F. and Vogt G., 2003. Parthenogenesis in an outsider crayfish. Nature, 421, 806.

Söderhäll K. and Cerenius L., 1992. Crustacean immunity. Annu. Rev. Fish Dis., 2, 3-23.

Schulz H.K., Smietána P., Maiwald T., Oidtmann B. and Schulz R., 2006. Case studies on the cooccurrence of Astacus astacus (L.) and Orconectes limosus (Raf.): snapshots of a slow displacement. Freshw. Crayfish, 15, 212-219.

Strand D.A., Holst-Jensen A., Viljugrein H., Edvardsen B., Klaveness D., Jussila J. and Vrålstad T., 2011. Detection and quantification of the crayfish plague agent in natural waters: direct monitoring approach for aquatic environments. Dis. Aquat. Organ., 95, 9-17.

Svoboda J., Strand D.A., Vrålstad T., Grandjean F., Edsman L., Kozák P., Kouba A., Fristad R.F., Koca S.B. and Petrusek A., 2014. The crayfish plague pathogen can infect freshwater-inhabiting crabs. Freshw. Biol., 59, 918-929.

Tilmans M., Mrugała A., Svoboda J., Engelsma M.Y., Petie M., Soes D.M., Nutbeam-Tuffs S., Oidtmann B., Roessink I. and Petrusek A., 2014. Survey of the crayfish plague pathogen presence in the Netherlands reveals a new Aphanomyces astaci carrier. J. Invertebr. Pathol., 120, 74-79.

Tuffs S. and Oidtmann B., 2011. A comparative study of molecular diagnostic methods designed to detect the crayfish plague pathogen, Aphanomyces astaci. Vet. Microbiol., 153, 343-353.

Unestam T., 1969. On the Adaptation of Aphanomyces astaci as a Parasite. Physiol. Plantarum, 22, 221-235.

Unestam T. and Weiss D.W., 1970. The Host-Parasite Relationship between Freshwater Crayfish and the Crayfish Disease Fungus Aphanomyces astaci: Responses to Infection by a Susceptible and a Resistant Species. J. Gen. Microbiol., 60, 77-90.

Vennerström P., Söderhäll K. and Cerenius L., 1998. The origin of two crayfish plague (Aphanomyces astaci) epizootics in Finland on noble crayfish, Astacus astacus. Ann. Zool. Fenn., 35, 43-46.

Viljamaa-Dirks S., Heinikainen S., Torssonen H., Pursiainen M., Mattila J. and Pelkonen S., 2013. Distribution and epidemiology of genotypes of the crayfish plague agent Aphanomyces astaci from noble crayfish Astacus astacus in Finland. Dis. Aquat. Organ., 103, 199-208.

Vrålstad T., Knutsen A.K., Tengs T. and Holst-Jensen A., 2009. A quantitative TaqMan ${ }^{\circledR}$ MGB real-time polymerase chain reaction based assay for detection of the causative agent of crayfish plague (Aphanomyces astaci). Vet. Microbiol., 137, 146-155. 